\title{
Modeling of Permanent Wilting from Particle Size Fractions of Coastal Plain Sands Soils in Southeastern Nigeria
}

\author{
Chinedu Innocent Obi, ${ }^{1}$ Jude C. Obi, ${ }^{2}$ and Emmanuel U. Onweremadu ${ }^{1}$ \\ ${ }^{1}$ Department of Soil Science and Technology, Federal University of Technology, Owerri, PMB 1526 Owerri, Nigeria \\ ${ }^{2}$ Department of Soil Science, University of Uyo, PMB 1017 Uyo, Nigeria \\ Correspondence should be addressed to Chinedu Innocent Obi, innocentck@yahoo.com
}

Received 29 April 2012; Accepted 28 May 2012

Academic Editors: M. Bernoux and Z. L. He

Copyright ( 92012 Chinedu Innocent Obi et al. This is an open access article distributed under the Creative Commons Attribution License, which permits unrestricted use, distribution, and reproduction in any medium, provided the original work is properly cited.

\begin{abstract}
Permanent wilting points in soils have been found to correlate significantly with particle size fractions. This study was conducted to establish functional relationship between soil particle size fractions and permanent wilting point of soils of coastal plain sands in southeastern Nigeria. A total of 102 surface samples were collected from three different dominantly Ultisols toposequences (i.e., 34 samples from each). Permanent wilting point experiment was carried out in pots with the 102 samples in the greenhouse while the particle size analysis was carried out in the laboratory. There was significant correlation among the textural separates, permanent wilting point correlated significantly with clay $(r=0.21, P \leq 0.05)$. The general linear model showed significant differences between permanent wilting point of soils found in the upper and lower slope positions. Regression equation established that $54 \%$ of the total variation in permanent wilting point could be accounted for by the clay and coarse sand content of the soils. Prediction of permanent wilting point of Ultisols formed on coastal plain sands soils of humid tropical southeastern Nigeria will effectively depend on reliability of determination of clay and coarse sand contents of the soils.
\end{abstract}

\section{Introduction}

A fundamental concept in modeling is to simplify reality into ideas called models which contain only those elements that are meaningful or that could lead to a particular desired objective. In the most simplified form but typically models are simplified representations of a system, such as a soil system. Soil water retention is defined by capillarity, which is the result of adhesion and cohesion. In addition, capillarity depends on the structure of the soil pores. Since water retention of soils is affected by physical properties, such as structure and texture, it is possible to develop empirical relationships to predict soil water retention. Developments in computer modeling accelerate these studies [1]. Spatial variability of soil properties, including the soil matrix, on a toposequence is inherent in nature due to the influence of geogenetic/pedogenetic processes and management/land use related activities. Pedogenetic (intrinsic) variables interact with each other across spatial and temporal scales and their effects are further modified by erosional and depositional processes [2] which influence landscape/toposequence evolution. Although soil texture is a permanent attribute of a soil, the proportion of soil matrix of sand, silt and clay have been found to be spatially variable by several studies [3-6].

Particle sizes are the major components of a mineral soil. Particle sizes, their derivates, and solute transport in soils have been found to be correlated and dependent [7], subsequently, other physical properties $[8,9]$ and their mineralogy [6]. Duffera et al. [4] conducted two mixed-model analyses and principal component analysis to describe the field scale horizontal and vertical variability of soil physical properties and their relations to soil map units in typical southeastern US coastal plain sands soils. Their results indicated that some of the soil physical properties such as texture, soil water content, and plant available water showed significant spatial structure and were captured by soil map units.

Soils of southeastern Nigeria formed on unconsolidated coastal plain sands are characterized by the dominance of sandy textured fragments comprising larger quantities of coarse over fine-textured materials, have low fertility due to 
dominance of low activity clays and inherent low organic matter contents $[10,11]$. Solute transport in soils have been found to correlate with particle sizes [7], and soils with greater proportion of clay contents tend to retain more water. Thus, if a dependency equation can be generated, between the soil particle sizes and permanent wilting point, then a threshold for water requirement limits can be drawn, and water can easily be supplied to the crops when it is needed.

In the past, attempts were made to correlate basic soil properties such as size fractions (sand, silt, and clay) and organic carbon with water content held at certain hydraulic potentials (usually at $1 / 3 \mathrm{~atm}$ and $15 \mathrm{~atm}$ ). This was made in order to estimate water content at field capacity and permanent wilting point and the availability of water to plants [12].

The objective of this study therefore was to determine the functional relationship between soil particle sizes and permanent wilting point of soils of coastal plain sands in southeastern Nigeria. For this aim, the use of particle size distribution and pot indicator (maize) plants, which are measured easily and inexpensively in most areas, were employed.

\section{Materials and Methods}

2.1. Description of the Study Area. The study was carried out in three different toposequences of soils namely, soils from Holy family college (HFC), Technical college (TCHC), and Science college (SCC) all located in Abak Local Government Area in Akwa Ibom State in southeastern Nigeria. Soils of the three locations were derived from coastal plain sands and have been altered by cultivation. In Holy family college, Telferia occidentalis were planted in the sampling area, in Technical College; soils have been cultivated but were under fallow during the sampling period and were dominated by Pennisetum digitatum while the Science College had arable crops such as Manihot esculenta and Zea mays. Abak is located approximately between longitudes $4^{\circ} 58^{\prime}$ and $4^{\circ} 62^{\prime} \mathrm{E}$ and latitude $7^{\circ} 47^{\prime}$ and $7^{\circ} 50^{\prime} \mathrm{N}$ within a tropical climate characterized by rainy season (February/March-November) and dry season (November-February/March). Annual rainfall ranges from $3000 \mathrm{~mm}$ along the Atlantic coast to $2000 \mathrm{~mm}$ in the hinterland (SLUS-AK, 1989). The state falls within the sedimentary areas of Nigeria with up to $80 \%$ of the soils formed on coastal plain sands and alluvium $[10,11]$ comprising the whole of the southern and central parts of the state.

2.2. Soil Sampling and Laboratory Analysis. In the field, surface samples were collected on each of the toposequence/landform (about $100 \mathrm{~m} \times 60 \mathrm{~m}$ ) plots at $5 \mathrm{~m}^{2}$ interval (i.e., grid nodes) with the aid of Dutch auger. In each of the sampling areas (the schools), nine (9) replicate samples were collected perpendicular to the direction of the upper slope, sixteen (16) were also collected from the middle slope, while nine (9) were collected again from the bottom slope. A total of 102 samples $[(9 \times 3)+(16 \times 3)+(9 \times 3)]$ were collected from the three toposequences. Particle sizes may not have varied very differently from the three toposequences, but samples were collected as described to increase replication so as to enlarge the degree of freedom in estimating the error variance in conducting this experiment. Samples were processed, and particle size analysis was carried out [13]. $50 \mathrm{~g}$ of air-dried soil sample was mixed with $20 \mathrm{~mL}$ of calgon and $100 \mathrm{~mL}$ of distilled water in a milk shake cup and was shaken in a mechanical shaker for 5 minutes. The mixture was totally transferred into a $1000 \mathrm{~mL}$ glass cylinder and was made up to $1000 \mathrm{~mL}$ volume with distilled water. The content in the cylinder was then shaken by inversion for 10 times, holding the base with one palm and covering the open end with the other palm. The temperature and hydrometer readings were taken within one minute after keeping the cylinder down on a desk. Also the temperature and hydrometer readings were taken after 3 hours without shaking. These were repeated for all the samples. Particle size fractions were expressed in grams per kilogram using a standard mathematical formula. Permanent wilting point was determined as was explained in the Laboratory Manual for Agronomic Studies in Soil, Plant and Microbiology, University of Ibadan [14]. A quantity of air-dried, $2 \mathrm{~mm}$ sieved soil collected from the various sampling points in the three topographic positions of the three toposequences, with enough water to give a good crumb structure was prepared. About 3 maize grains were sown in each pot and a little more water was added. The seedlings were thinned down to 1 per pot and aluminium ring was put round each plumule before the coleoptiles opened and was pressed a little way into the soil. The seedlings were allowed to develop about 4 leaves and the soil surface was later sealed up with a layer of molten paraffin wax about 1/4 inches thick. The space between the stem of the seedling and the aluminium ring was plugged with cotton wool and the plants were left to grow until the first definite signs of wilting appear. On noticing wilting, the plants were taken under a shade and left over night to see if turgor is regained, if so it is taken out again until it cannot be able to regain turgor under a shade. When permanent wilting was established the stem was cut and the wax and roots was also removed. The soil samples were weighed and then ovendried and weighed again. The difference between the two weights was expressed as a percentage of the oven-dried soils known as permanent wilting point.

2.3. Statistical Analysis. Data collected were summarized using descriptive statistics, and normality of distribution was tested with skewness and kurtosis. The general linear model univariate procedure was used to model the values of the parameters based on their relationship to categorical and scale predictors. Correlation and multiple regression analysis were carried out to find out the way variables relate with each other. All statistical analysis was carried out with the aid of SAS [15].

\section{Results and Discussion}

The mean and median were used as primary estimates of central tendency, while standard deviations, skewness, kurtosis, minimum, and maximum were used as estimates of variability (Table 1). The soil properties were neither skewed nor kurtous in the entire sites with the exception of silt 
TABLE 1: Descriptive Statistics of some physical properties of soils of the study sites.

\begin{tabular}{lcccccccc}
\hline Variable & SD & SE & Skewness & Kurtosis & Mean & Median & Min. & Max. \\
\hline PWP $(\%)$ & 4.33 & 0.43 & 0.02 & -0.39 & 15.04 & 14.80 & 4.44 & 27.40 \\
Sand $\left(\mathrm{g} \mathrm{kg}^{-1}\right)$ & 19.49 & 1.93 & -0.73 & -0.14 & 889.85 & 895.65 & 843.20 & 926.20 \\
Coarse sand $\left(\mathrm{g} \mathrm{kg}^{-1}\right)$ & 47.81 & 4.73 & -0.30 & -1.47 & 760.78 & 782.45 & 668.00 & 825.40 \\
Fine sand $\left(\mathrm{g} \mathrm{kg}^{-1}\right)$ & 36.57 & 3.62 & 0.62 & -0.56 & 128.83 & 119.50 & 79.40 & 239.20 \\
Silt $\left(\mathrm{g} \mathrm{kg}^{-1}\right)$ & 13.62 & 1.35 & 1.03 & 1.31 & 42.64 & 40.55 & 20.80 & 89.60 \\
Clay $\left(\mathrm{g} \mathrm{kg}^{-1}\right)$ & 12.92 & 1.28 & 0.32 & -0.36 & 67.52 & 64.80 & 40.20 & 99.40 \\
SCR & 0.28 & 0.03 & 2.70 & 10.45 & 0.66 & 0.62 & 0.26 & 2.08 \\
Clay ratio & 3.04 & 0.30 & 0.75 & 1.03 & 14.37 & 14.44 & 9.05 & 23.88 \\
\hline
\end{tabular}

PWP: permanent wilting point, SCR: silt clay ratio, SD: standard deviation, and SE: standard error of mean.

TABLE 2: General linear model of some parameters in the topographic positions of the study sites.

\begin{tabular}{lccc}
\hline & Upper & Middle & Lower \\
\hline PWP $(\%)$ & $14.40^{\mathrm{b}}$ & $15.85^{\mathrm{a}}$ & $16.44^{\mathrm{a}}$ \\
Sand $\left(\mathrm{g} \mathrm{kg}^{-1}\right)$ & $881.34^{\mathrm{b}}$ & $889.28^{\mathrm{b}}$ & $874.00^{\mathrm{a}}$ \\
Fine sand $\left(\mathrm{g} \mathrm{kg}^{-1}\right)$ & $124.91^{\mathrm{c}}$ & $105.89^{\mathrm{b}}$ & $161.52^{\mathrm{a}}$ \\
Coarse sand $\left(\mathrm{g} \mathrm{kg}^{-1}\right)$ & $765.75^{\mathrm{c}}$ & $793.27^{\mathrm{b}}$ & $712.57^{\mathrm{a}}$ \\
Silt $\left(\mathrm{g} \mathrm{kg}^{-1}\right)$ & $47.83^{\mathrm{a}}$ & $38.44^{\mathrm{b}}$ & $45.94^{\mathrm{a}}$ \\
Clay $\left(\mathrm{g} \mathrm{kg}^{-1}\right)$ & $60.83^{\mathrm{b}}$ & $62.31^{\mathrm{b}}$ & $80.04^{\mathrm{a}}$ \\
Silt clay ratio & $0.84^{\mathrm{b}}$ & $0.62^{\mathrm{a}}$ & $0.58^{\mathrm{a}}$ \\
\hline
\end{tabular}

PWP: permanent wilting point.

Means followed by different letters within the same row indicate significant difference at $P<0.05$.

clay ratio which was found to be kurtous. The mean and median values were similar with the median greater or less (with maximum of 21 points) than the mean for most of the soil particle sizes and permanent wilting point (Table 1). These showed that outliers did not dominate the measure of central tendency but the true indication of the particle size distribution and permanent wilting points of the soils of the study sites. Similarity of means and median of several physical, chemical, and biological soil properties had been reported by Obi and Ogunkunle [16], Shulka et al.[17], and Cambardella et al. [18]. To enhance the pragmatic aspect of the study, no transformation was attempted although Parkin and Robinson [19] had previously reported that many soil properties are log-normally distributed. Soil texture is a permanent attribute of the soil, and the descriptive statistics as shown in Table 1 indicated that the distribution of particle sizes are not very different from each other in the entire sites although the soil matrix was found to be spatially variable.

Table 2 shows the general linear model univariate $(\mathrm{Pr}>$ $|t|)$ of some parameters in different slope/topographic positions in the study sites. The general linear model (GLM) is used to model the value of a parameter based on its relationship to categorical and scale predictors. The GLM univariate procedure was used to perform a one-way ANOVA on some parameters on topographic positions of upper, middle, and lower in the three study sites. It was used to compare means and find out significant differences where they exist in the positions. The results shown in Table 2 reveals that the permanent wilting point of soils in the upper and lower topographic/slope positions of the study sites were significantly different from each other but not upper and middle or middle and lower slope positions. This could be due to variations in particle size distribution in the upper and lower topographic position as occurrence of clay particles is more on the lower position. This agrees with the findings of Bilal et al. [20] which stated that a significant negative relationship exists between permanent wilting point and sand fraction. Highly significant differences also exist between sand content of the upper and lower slope positions, and the middle and lower slope positions. The same trend was noticed in fine sand and coarse sand particles but the significant differences also include upper and middle slope positions. The clay particles in the upper slope position differed significantly with those of the lower slope positions and highly significant differences in clay particles was also pronounced between the middle and lower positions. Several studies inferred that clay contents of soils play a key role and as such a major predictor for modeling permanent wilting point of soils $[1,7,12,20]$. According to Bilal et al. [20], the permanent wilting point and clay showed a significant positive relationship at $P<0.001$. This also reflected in the general linear model results as shown in Table 2, significant differences existed between permanent wilting point of soils found in the upper slope position and the lower slope position and this could be explained largely by the differences that existed by the amount of clay particles in these slope position. Also significant differences existed between the silt clay ratio in the upper, middle, and lower slope positions (Table 2).

Table 3 shows the Pearson correlation coefficients for soil properties of the studied sites. Sand correlated negatively with permanent wilting point $(r=0.14, P<0.05)$ in the entire sites. This agrees with the findings of Bilal et al. [20] which stated that a significant negative relationship exists between the permanent wilting point and sand fraction. The proportion of coarse sand decreased as fine sand increased at a $93 \%$ rate $(r=-0.93, P<0.01)$. A significant negative relationship existed between the silt and sand $(r=0.75, P<$ 0.01 ). Clay was found to be positively correlated with the permanent wilting point even at a rate as low as $21 \%(r=$ 0.21, $P<0.05$ ). Bilal et al. [20] and Minansny et al. [1] have conducted similar studies and came up with the result 
TABle 3: Pearson correlation coefficients for soil properties of the study sites.

\begin{tabular}{|c|c|c|c|c|c|c|c|}
\hline & PWP & Sand & Fine sand & Coarse sand & Silt & Clay & SCR \\
\hline \multicolumn{8}{|l|}{ PWP (\%) } \\
\hline Sand $\left(\mathrm{g} \mathrm{kg}^{-1}\right)$ & -0.14 & & & & & & \\
\hline Fine sand $\left(\mathrm{g} \mathrm{kg}^{-1}\right)$ & -0.07 & $-0.39 * *$ & & & & & \\
\hline Coarse sand $\left(\mathrm{g} \mathrm{kg}^{-1}\right)$ & 0.003 & $0.71^{* *}$ & $-0.93^{* *}$ & & & & \\
\hline Silt $\left(\mathrm{g} \mathrm{kg}^{-1}\right)$ & 0.004 & $-0.75^{* *}$ & $0.25^{*}$ & $-0.51^{* *}$ & & & \\
\hline Clay $\left(\mathrm{g} \mathrm{kg}^{-1}\right)$ & $0.21^{*}$ & $-0.72 * *$ & $0.33^{* *}$ & $-0.54^{* *}$ & 0.08 & & \\
\hline SCR & -0.17 & $-0.26^{* *}$ & 0.12 & $-0.20^{*}$ & $0.81^{* *}$ & $-0.47^{* *}$ & \\
\hline Clay ratio & $-0.26^{* *}$ & $0.62 * *$ & $-0.22 *$ & $0.42 * *$ & 0.03 & $-0.97 * *$ & $0.58^{* *}$ \\
\hline
\end{tabular}

PWP: permanent wilting point, SCR: silt clay ratio, ${ }^{*}$ Significant at $5 \%,{ }^{*}$ Significant at $1 \%$.

that clay and permanent wilting points were significantly positively correlated. According to Strock et al. [7], solute transport in soils have been found to be correlated with particle sizes and soils with greater proportion of clay contents will tend to retain more water. From this inference, it is clear that the permanent wilting point of such soils will be higher. This could be as a result of large surface area of clay particles with large number of charges to attract water molecules. The silt-clay ratio correlated negatively and highly significantly with sand $(r=0.26, P<0.01)$.

Multiple regression analysis was carried out in order to establish contributions of predictors (clay and coarse sand) to permanent wilting points. This was because clay contents of soils play a key role and as such a major predictor for modeling permanent wilting point of soils $[1,7,12,20]$. A look at the Table 3 justifies this point. Clay and coarse sand were used as the predictors (independent variable), while the permanent wilting point (PWP) is dependent and the relationship was established as:

PWP $=-2.99+0.10$ (clay) +0.02 (coarse sand $),\left(r^{2}=\right.$ $0.54, P \leq 0.05)$.

The regression line gave a fair fit to the observed data since it explains $54 \%$ of the total variation in permanent wilting point around the mean of clay and coarse sand contents. This therefore goes a long way to say that prediction of permanent wilting point of Ultisols formed on coastal plain sands soils of humid tropical southeastern Nigeria will effectively depend on reliability of determination of clay and coarse sand contents of the soils.

\section{Conclusion}

The soil properties were neither skewed nor kurtous in the entire sites and thus outliers did not dominate the central tendency. There was correlation between the permanent wilting point and the soil particle sizes and between the particle sizes themselves. Clay and permanent wilting point correlated significantly positively while coarse sand and clay correlated highly significantly but negatively. The permanent wilting point of soils in the upper slope positions differed significantly with those of the lower positions so as did the clay and coarse sand contents differ accordingly. Higher permanent wilting points were discovered at the lower slope positions. The regression line explains $54 \%$ of the total variation in permanent wilting point around the mean of clay and coarse sand contents. Prediction of permanent wilting point of Ultisols formed on coastal plain sands soils of humid tropical southeastern Nigeria will effectively depend on reliability of determination of clay and coarse sand contents of the soils.

\section{References}

[1] B. Minasny, A. B. McBratney, and K. L. Bristow, "Comparison of different approaches to the development of pedotransfer functions for water-retention curves," Geoderma, vol. 93, no. 3-4, pp. 225-253, 1999.

[2] J. D. Phillips, "Development of texture contrast soils by a combination of bioturbation and translocation," Catena, vol. 70, no. 1, pp. 92-104, 2007.

[3] J. Iqbal, J. A. Thomasson, J. N. Jenkins, P. R. Owens, and F. D. Whisler, "Spatial variability analysis of soil physical properties of alluvial soils," Soil Science Society of America Journal, vol. 69, no. 4, pp. 1338-1350, 2005.

[4] M. Duffera, J. G. White, and R. Weisz, "Spatial variability of Southeastern U.S. Coastal Plain soil physical properties: implications for site-specific management," Geoderma, vol. 137, no. 3-4, pp. 327-339, 2007.

[5] P. Santra, U. K. Chopra, and D. Chakraborty, "Spatial variability of soil properties and its application in predicting surface map of hydraulic parameters in an agricultural farm," Current Science, vol. 95, no. 7, pp. 937-945, 2008.

[6] Z. M. Souza, J. M. Junior, and G. T. Pereira, "Spatial variability of the physical and mineralogical properties of the soil from the areas with variation in landscape shapes," Brazilian Archives of Biology and Technology, vol. 52, no. 2, pp. 305-316, 2009.

[7] J. S. Strock, D. K. Cassel, and M. L. Gumpertz, "Spatial variability of water and bromide transport through variably saturated soil blocks," Soil Science Society of America Journal, vol. 65, no. 6, pp. 1607-1617, 2001.

[8] J. Mbagwu, R. Lal, and T. W. Scott, "Physical properties of three soils in southern Nigeria," Soil Science, vol. 136, no. 1, pp. 48-55, 1983.

[9] P. I. Ogban and I. O. Ekerette, "Physical and chemical properties of the coastal plain sands soils of southeastern Nigeria," Nigerian Journal of Soil and Environmental Research, vol. 2, pp. 6-14, 2001.

[10] A. G. Ojanuga, G. Lekwa, and F. O. R Akamigbo, "Survey, classification and genesis of acid sands," in "Acid Sands" of Southeastern Nigeria, E. J. Udo and R. A. Sobulo, Eds., Soil 
Science Society of Nigeria Special Publication Monograph No. 1, pp. 1-7, 1981.

[11] G. E. K. Ofomata, "Actual and potential erosion in Nigeria and measures for control," in "Acid Sands" of Southeastern Nigeria, E. J. Udo and R. A. Sobulo, Eds., Soil Science Society of Nigeria Special Publication Monograph No. 1, pp. 151-165, 1981.

[12] R. Kaur, S. Sandar, H. P. Gurung et al., "Evaluation of pedotransfer functions for predicting field capacity and wilting point soil moisture contents from routinely surveyed soil texture and organic carbon data," Journal of the Indian Society of Soil Science, vol. 5, pp. 205-208, 2002.

[13] Gee, G. W, and J. W. Bauder, "Particle size analysis," in Methods of Soil Analysis Part 1, A. Klute, Ed., pp. 91-100, American Society of Agronomy, Madison, Wis, USA, 1986.

[14] C. T. I. Odu, O. Babalola, E. J. Udo, A. O. Ogunkunle, T. A. Bakare, and G. O. Adeoye, Laboratory Manual for Agronomic Studies in Soil, Plant and Microbiology, University of Ibadan, 1986.

[15] SAS Institute, SAS/STST User's Guide, Version 8, SAS Institute, Carry, NC, 1999.

[16] J. C. Obi and A. O. Ogunkunle, "Influence of termite infestation on the spatial variability of soil properties in the Guinea savanna region of Nigeria," Geoderma, vol. 148, no. 3-4, pp. 357-363, 2009.

[17] M. K. Shukla, B. K. Slater, R. Lal, and P. Cepuder, "Spatial variability of soil properties and potential management classification of a chernozemic field in lower Austria," Soil Science, vol. 169, no. 12, pp. 852-860, 2004.

[18] C. A. Cambardella, T. B. Moorman, J. M. Novak et al., "Fieldscale variability of soil properties in central Iowa soils," Soil Science Society of America Journal, vol. 58, no. 5, pp. 15011511, 1994.

[19] T. B. Parkin and J. A. Robinson, "Analysis of lognormal data," Advances in Soil Sciences, vol. 20, pp. 193-325, 1992.

[20] C. Bilal, M. Ramazan, A. Mehmet, and M. Hasan, "Pedotransfer functions for the estimation of the field capacity and permanent wilting point," Pakistan Journal of Biological Sciences, vol. 7, no. 4, pp. 535-541, 2004. 

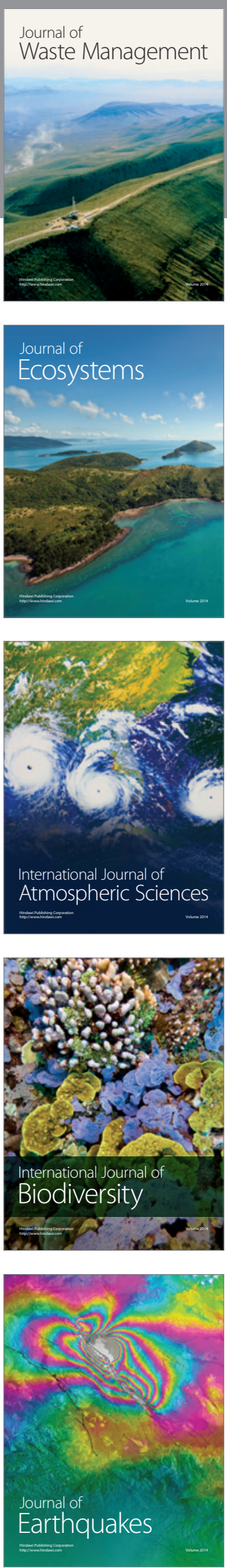
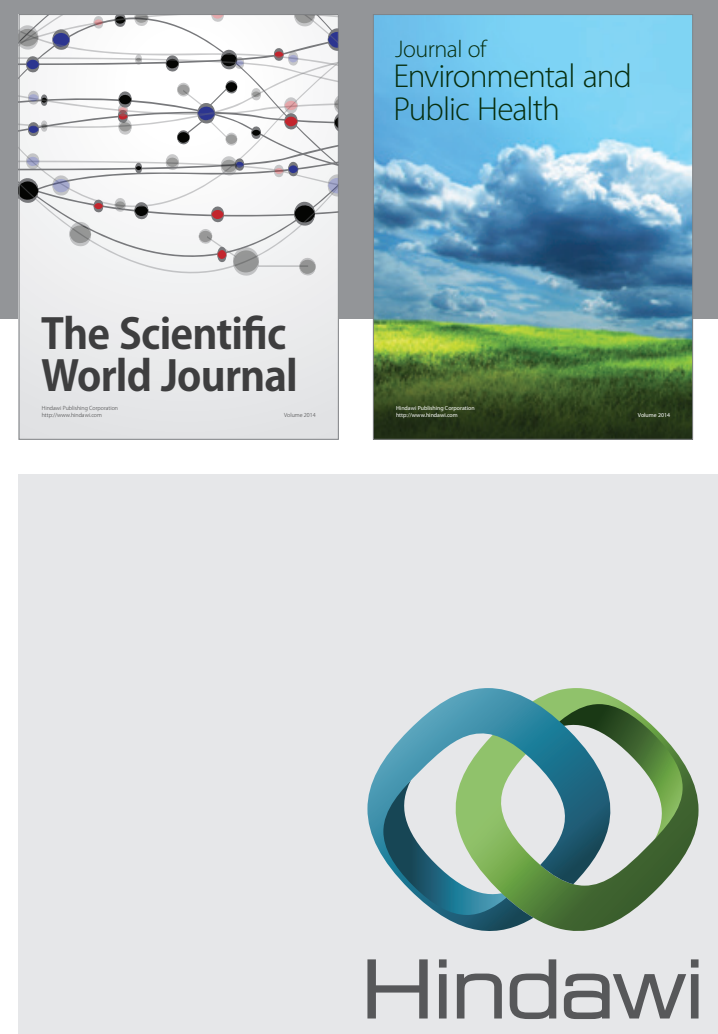

Submit your manuscripts at

http://www.hindawi.com
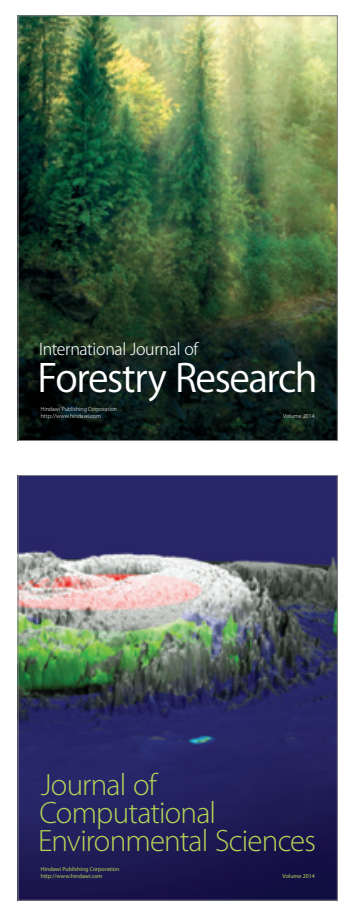
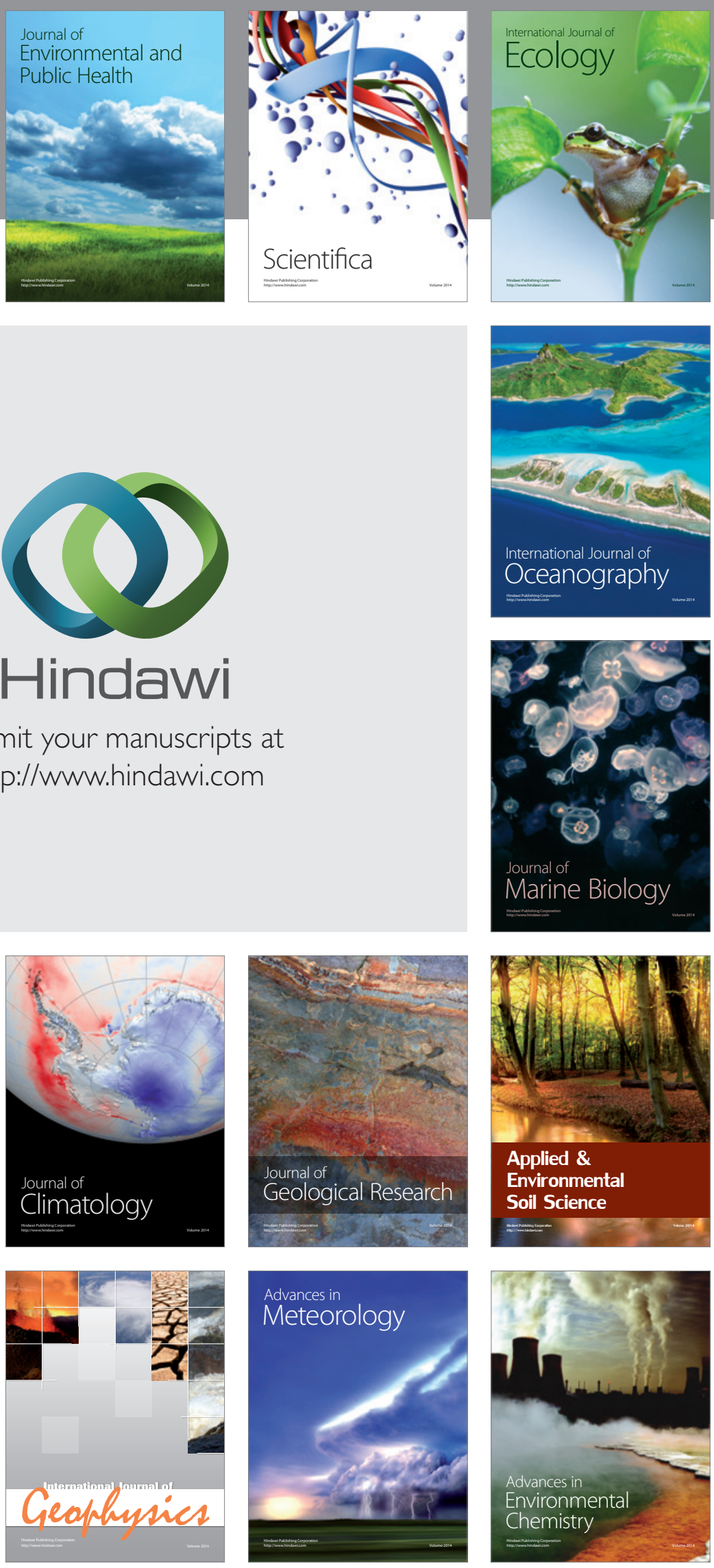